\title{
Soil hydraulic conductivity as affected by physical and chemical properties of effluents
}

\author{
Lionel METZGER, Bruno YARON \& Uri MINGELGRIN
}

Institute of Soils and Water, ARO, The Volcani Center, ISR 50-250 Bet Dagan

\section{SUMMARY}

The objective of this work was to evaluate the contributions of the physico-chemical factors which may cause reduction in soil hydraulic conductivity $\left(\mathrm{K}_{\mathrm{sat}}\right)$ upon land disposal of sewage effluent. In particular the binding of polyvalent metals by organic molecules and the plugging by suspended solids were studied. The binding capacity of effluents discharged from oxidation ponds was determined with the aid of gel chromatography. The range of binding capacity found lies between 8 and $25 \%$ of the total $\mathrm{Ca}+\mathrm{Mg}$ content of the effluent. The effect of this binding on the exchangeable sodium percentage (ESP) of two soils and a standard clay was determined. Columns packed with a sand and a sandy loam were leached with unfiltered effluents and with the same effluents after different degrees of filtration. Subsequently, distilled water was applied to the same columns. Filtered effluent caused approximately a $20 \%$ reduction in $\mathrm{K}_{\text {sal }}$ for both soils, whereas more than double this reduction was caused by unfiltered effluent. The results show that the main mechanism responsible for the immediate decrease in soil $\mathbf{K}_{\mathrm{sat}}$ upon effluent application may be the physical pore plugging by suspended solids. The binding of polyvalent cations may cause a further reduction in $\mathbf{K}_{\mathrm{sat}}$ when irrigation with high quality water or rain succeed the effluent application.

Additional key words : Sewage water, physical plugging, suspended solids, polyvalent cations binding, sodium adsorption ratio.

Effet des propriétés physiques et chimiques des effluents d'eaux résiduaires sur la conductivité hydraulique des sols.

L'objectif de ce présent travail est de faire la part respective des facteurs physico-chimiques qui peuvent provoquer une réduction de la conductivité hydraulique $\left(\mathrm{K}_{\mathrm{sat}}\right)$ des sols lors de l'épandage d'eaux résiduaires. La complexation des métaux polyvalents par les molécules organiques et le colmatage par les matières en suspension (MES) ont été étudiés en particulier. La capacité de complexation dans des effluents obtenus à la sortie de bassins d'oxydation a été déterminée à l'aide de la chromatographie sur gel. Les valeurs de capacité de complexation trouvées sont comprises entre 8 et 25 p. 100 de la concentration totale en $\mathrm{Ca}+\mathrm{Mg}$ de l'effluent. L'effet de cette complexation sur le pourcentage en sodium échangeable de deux sols et d'une argile standard a été déterminé. Des colonnes remplies d'un sable et d'un sable limoneux ont été lessivées avec des effluents non filtrés et ces mêmes effluents après divers degrés de filtration. Par la suite, de l'eau distillée a été versée sur ces mêmes colonnes. L'effluent filtré provoque approximativement une réduction de $\mathbf{K}_{\text {sat }}$ de 20 p. 100 , tandis que l'effluent non filtré provoque au moins une réduction double. Les résultats obtenus indiquent que le principal mécanisme responsable de la décroissance immédiate de $\mathbf{K}_{\mathrm{sat}}$ des sols, due à l'application d'effluents, semble être le colmatage physique des pores par les MES. La complexation des cations polyvalents pourrait provoquer une réduction supplémentaire de $\mathrm{K}_{\mathrm{sat}}$, au cas où une irrigation avec une eau de bonne qualité ou la pluie succède à l'irrigation avec ces effluents.

Mots clés additionnels : Eaux résiduaires, colmatage physique, matières en suspension, complexation des cations polyvalents, sodium adsorption ratio.

\section{INTRODUCTION}

The nonbiological reduction of hydraulic conductivity $\left(\mathrm{K}_{\text {sat }}\right)$ upon effluent disposal has been explained in different ways. The clogging of soils has often been attributed to the accumulation of suspended solids (THOMAS et al., 1966; DE VRIES, 1972 ; DANIEL \& BOUMA, 1974 ; KRISTIANSEN,
1981). The effect of the suspended solids content of effluent on the $K_{\text {sat }}$ was studied recently by VINTEN et al. (1983).

The contribution of the quantity and nature of the electrolytes in the sewage effluent to the hydraulic properties of soils has been treated in the past in a similar way to that used in conventional irrigation water (THOMAS \& LAW, 1968 ; BURNS \& RAWITZ, 1981). The recently demonstrated 
capacity of organic solutes in sewage water to bind polyvalent cations (S POSITO et al., 1978: ACHER et al., 1981) motivated the redefinition of the effective sodium adsorption ratio (SAR) of effluents as related to the effect of effluent disposal on soil $\mathrm{K}_{\mathrm{sat}}$. It was shown that binding of $\mathrm{Ca}^{2+}$ and $\mathrm{Mg}^{2+}$ increased the effective $\mathrm{SAR}$ of sewage effluent and thus contributed to the decrease in hydraulic conductivity observed in soils to which the effluents were applied (PISTOL, 1981).

Since sewage effluents are characterized by the simultaneous presence of organic and inorganic solids, organic solutes and inorganic electrolytes at various concentrations and ionic ratios, their effect on soil $\mathrm{K}_{\text {sat }}$ is probably due to a number of interrelated factors. The present study deals with the effect of various physical and chemical properties of sewage effluents on the hydraulic properties of soils. This information is of great importance for irrigation with effluents and for land disposal technology in general. The contribution of the suspended particles and of the binding of soluble bivalent metals in the applied effluents to the change in soil $\mathbf{K}_{\mathrm{sat}}$ upon land disposal of the effluent is emphasized.

\section{MATERIALS AND METHODS}

\section{A. Materials}

Two soils were investigated and their characteristics are presented in table 1. Soil samples which passed through a $1 \mathrm{~mm}$ sieve were used. Effluents from Eilat, Gan Raveh and Ramat Hasharon municipal treatment plants were studied. Table 2 summarizes the properties of the effluents. Fisher bentonite (Na), Sephadex G10 and analytical grade chloride salts $\left(\mathrm{MgCl}_{2}, \mathrm{CaCl}_{2}, \mathrm{NaCl}\right)$ were used.

\section{B. Procedure}

\section{Cation binding}

The procedure for the separation of bound and free $\mathrm{Ca}^{2+}$ and $\mathrm{Mg}^{2+}$ ions using Sephadex gel was described by ACHER et al. (1981). Samples of $1 \mathrm{~cm}^{3}$ volume were applied to the top of a gel column and then eluted with $50 \mathrm{ml}$ of $0.01 \mathrm{~N} \mathrm{CaCl}_{2}$. $\mathrm{Ca}^{2+}$ and $\mathrm{Mg}^{2+}$ concentrations were determi-

TABLE 1

Characteristics of the soils used in the experiments.

Caractéristiques des sols utilisés dans nos expériences.

\begin{tabular}{|c|c|c|c|c|c|c|c|c|}
\hline Soil & $\begin{array}{c}\text { Sand } \\
(>20 \mu)\end{array}$ & $\begin{array}{c}\text { Silt } \\
(2-20 \mu) \\
\%\end{array}$ & $\begin{array}{c}\text { Clay } \\
(<2 \mu)\end{array}$ & $\begin{array}{c}\text { CEC } \\
\text { meq/100 g }\end{array}$ & $\underset{\%}{\mathrm{CaCO}_{3}}$ & $\mathrm{pH}$ & $\begin{array}{c}\text { Organic } \\
\text { matter } \\
\%\end{array}$ & $\begin{array}{l}\text { Dominant clay } \\
\text { minerals }\end{array}$ \\
\hline $\begin{array}{l}\text { Netanya }\left({ }^{a}\right) \\
\text { Sand }\end{array}$ & 92 & 5 & 3 & 2.7 & 0 & 7.7 & 0.05 & $\begin{array}{l}\text { Montmorillonitc } \\
\text { and Kaolinite }\end{array}$ \\
\hline $\begin{array}{l}\text { Bet Dagan }\left(^{b}\right) \\
\text { Sandy loam }\end{array}$ & 86 & 0 & 14 & 8.5 & 2.3 & 7.9 & 0.7 & Montmorillonitc \\
\hline
\end{tabular}

(a) C Horizon

(b) A Horizon

TABLE 2

Characteristics of the sewage effluents used in the experiments $\left(^{a}\right)$.

Caractéristiques des effluents d'eaux résiduaires utilisés dans nos expériences $\left({ }^{a}\right)$.

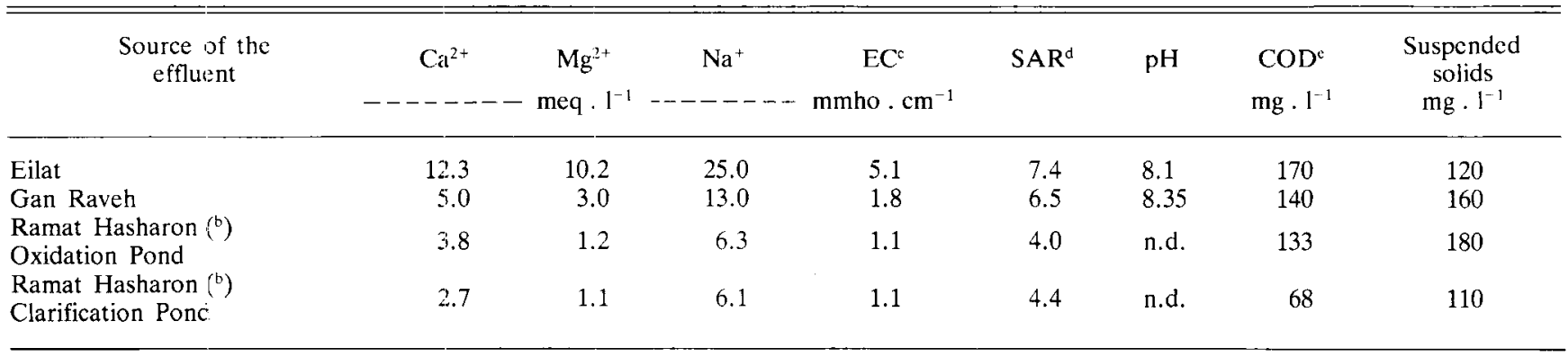

(a) All parameters were checked for the effluent filtered through Whatman 91 paper except for the SS which were checked for the unfiltercd effluent.

(a) Tous les paramètres ont ćté déterminés pour l'efflucnt filtré à travers du papier filtre Whatman 91, à l'exception des matières en suspension déterminées pour l'effluent non filtré.

(b) From PIsTol, 1981.

(c) Electrical concluctivity.

(d) Sodium adsorption ratio.

(c) Chemical oxygen demand. 
ned in $1 \mathrm{~cm}^{3}$ portions collected with a fraction collector at the bottom of the column. Bound and free forms appeared as different peaks on the chromatogram.

\section{Cation chemistry and exchangeable sodium percentage} (ESP)

The effect of equilibration of soils and clay with the effluents on the composition of the exchange complex was compared to the effect of equilibration with model solutions of the same $\mathrm{Ca}^{2+}, \mathrm{Mg}^{2+}$ and $\mathrm{Na}^{+}$content. The exchangeable cations in soils and in homoionic $\mathrm{Na}$ and $\mathrm{Ca}$ montmorillonite (prepared from Fisher bentonite), after contact with the effluents and the model solution were measured by ammonium acetate extraction. The exchangeable cations were determined in soil columns after 10 pore volumes had been applied to the soils. It was ascertained that a steadystate was achieved by then. In the case of the pure clays batch experiments were done. A Perkin Elmer 460 atomic absorption spectrophotometer was used for the determination of $\mathrm{Ca}^{2+}$ and $\mathrm{Mg}^{2+}$.

\section{Colloidal plugging}

Measurements assessing the importance of suspended colloids in altering the $\mathrm{K}_{\text {sat }}$ were made by comparing the effluent movement through soil columns after different degrees of filtration. Unfiltered effluents as well as effluents filtered through Whatman 91 or through millipore $0.45 \mu$ filters were investigated. In table 3 , the suspended solids contents and associated characteristics of Eilat effluents after the different filtration procedures are presented.

\section{Hydraulic conductivity}

Soil columns $12 \mathrm{~cm}$ long and $5 \mathrm{~cm}$ in diameter were mechanically packed to uniform densities (Netanya soil $1.45 \mathrm{~g} / \mathrm{cm}^{3}$; Bet Dagan soil $1.35 \mathrm{~g} / \mathrm{cm}^{3}$ - table 1 ), using a device described by YARON et al. (1965). Columns were presaturated with the effluent by upward wetting. Effluent was run through the columns under a constant head of $1 \mathrm{~cm}$ of water. A fraction collector was used to follow the flow rate as a function of the leachate volume until a steady-state was achieved (less than 4 hours). Immediately afterwards the column was eluted with distilled water and the flow rate was again followed. The $\mathrm{K}_{\text {sat }}$ was determined from the flow rate using Darcy's law.

\section{RESULTS AND DISCUSSION}

\section{A. $\mathrm{Ca}^{2+}$ and $\mathrm{Mg}^{2+}$ binding}

In conventional irrigation water the SAR-ESP (sodium adsorption ratio-exchangeable sodium percentage) relations are a well-known tool for estimating the effect of water quality on the soil $\mathrm{K}_{\text {sat }}$ (e.g. QUIRK \& SCHOFIELD, 1955 ; FRENKEL et al., 1978). If organic solutes in the added effluents have a binding capacity for polyvalent metals, it is instructive to estimate the effect of such binding on the resulting $\mathbf{K}_{\mathrm{sat}}$. Table 4 presents the binding capacity of the effluents studied. It may be observed that the binding capacity is between $8-26 \%$ of the soluble $\mathrm{Ca}^{2+}+\mathrm{Mg}^{2+}$ content.

Adsorption and desorption, precipitation and biological reaction may cause a reequilibration between the bound and unbound cations in the effluent after it is added to the soil. However, after that steady state is achieved, the effect of the equilibrium binding capacity on the soil's exchange complex may be defined in many cases by the relation:

$$
\mathrm{SAR}_{\mathrm{l}}=\frac{\mathrm{Na}^{+}}{\left[\frac{\mathrm{Ca}_{\mathrm{F}}^{2+}+\mathrm{Mg}_{\mathrm{F}}^{2+}}{2}\right]^{1 / 2}}
$$

where $\mathrm{Ca}_{\mathrm{F}}^{2+}$ and $\mathrm{Mg}_{\mathrm{F}}^{2+}$ are the unbound cations concentrations (meq/l) in the equilibrium soil solution, $\mathrm{Na}^{+}$is the sodium concentration (meq/l) and $\mathrm{SAR}_{\mathrm{E}}$ is the effective SAR which determines the ESP in the soil according to the modified Gapon equation :

$$
\mathrm{ESP}=\frac{\mathrm{K}_{\mathrm{G}} \mathrm{SAR}_{\mathrm{I}}}{1+\mathrm{K}_{\mathrm{G}} \mathrm{SAR}_{\mathrm{l}}}
$$

where ESP is the exchangeable sodium percentage and $\mathrm{K}_{\mathrm{G}}$ is the Gapon coefficient.

The actual steady state ESP will be strongly dependent on the soil and effluent properties such as the presence of $\mathrm{CaCO}_{3}$ in soil, or the $\mathrm{pH}$ and $\mathrm{CO}_{3}^{2-} / \mathrm{HCO}_{3}^{-}$contents of the effluent. These effects are known (BowER et al., 1968) and will not be further discussed here. It may be expected, for example, that $\mathrm{CaCO}_{3}$ containing soils in which free $\mathrm{Ca}^{2+}$ is controlled by equilibrium with the solid $\mathrm{CaCO}_{3}$ will be less affected by the binding of divalent ions.

TABLE 3

Eilat effluents after various degrees of filtration: some properties and effects on the $K_{\text {sat }}$ of 2 soils.

\begin{tabular}{|c|c|c|c|c|c|}
\hline \multirow[t]{2}{*}{$\begin{array}{l}\text { Degree of } \\
\text { filtration }\end{array}$} & \multirow{2}{*}{$\begin{array}{c}\text { COD } \\
\mathrm{mg} \cdot \mathrm{I}^{-1}\end{array}$} & \multirow{2}{*}{$\begin{array}{c}\text { Optical } \\
\text { density } \\
(\lambda=400 \mathrm{~nm})\end{array}$} & \multirow{2}{*}{$\begin{array}{l}\text { Suspended } \\
\text { solids } \\
\mathrm{mg} \cdot 1^{-1}\end{array}$} & \multicolumn{2}{|c|}{$\begin{array}{c}\mathrm{K}_{\mathrm{sat}} \text { decrease }\left({ }^{\mathrm{a}}\right) \\
\left(\% \text { initial } \mathrm{K}_{\text {sat }}\right)\end{array}$} \\
\hline & & & & Bet Dagan soil & Netanya soil \\
\hline No filtration & n.d. & 0.33 & 50 & 53 & 65 \\
\hline Whatman 91 filter paper & 170 & 0.22 & 7 & 20 & 22 \\
\hline Millipore filter & 120 & 0.05 & 0 & 15 & 8 \\
\hline \multicolumn{6}{|l|}{$0.45 \mu$ Pore diameter } \\
\hline Model solution ( $\left.{ }^{b}\right)$ & 0 & 0 & 0 & 10 & 0 \\
\hline
\end{tabular}
Effluents d'Eilat après divers degrés de filtration: quelques propriétés et effets sur la conductivité hydraulique de 2 sols. 
TABLE 4

Binding capacity of some effluents. Capacité de complexation de quelques effluents.

\begin{tabular}{lcc}
\hline \hline \multicolumn{1}{c}{$\begin{array}{c}\text { Source of the } \\
\text { effluent }\end{array}$} & Binding capacity & $\begin{array}{c}\text { Bound to total } \\
\mathrm{Ca}+\mathrm{Mg} \text { in } \\
\text { filtered effluent } \\
(\%)\end{array}$ \\
\hline $\begin{array}{l}\text { Eilat } \\
\text { Gan Raveh }\end{array}$ & 5.6 & 25 \\
$\begin{array}{l}\text { Ramat Hasharon } \\
\text { Oxidation pond }\end{array}$ & 1.1 & 14 \\
Ramat Hasharon & 0.4 & 8 \\
Clarification pond & 1.0 & 26 \\
\hline
\end{tabular}

The effect of this binding on the ESP of the studied soils and of a standard clay is presented in table 5. Ramat Hasharon and Gan Raveh effluents raised the ESP of Fisher bentonite and the Netanya soil, respectively, abovc the ESP level reached upon contact with a model solution of the same SAR. Eilat effluent, on the other hand, brought the ESP of both Netanya and Bet Dagan soils to a level bclow that of the appropriate model solution. In this case, the factors mentioned above apparently overrode the effect of the binding capacity of the effluent on the ESP of the soil at steady state.

A model solution in which the SAR is equal to $S A R_{E}$ of the effluent before it is added to the soils was prepared. Its cffect on the ESP of the Netanya soil is given in table 5. In the case of both Eilat and Gan Raveh effluents, that ESP was larger than that resulting from elution with the effluent. This is a measure of the importance of different interactions of the effluent with the soil in reducing the effect of the binding of polyvalent cations in the effluent on the ESP of the soil.

In equations (1) and (2) it is assumed that exchangeable $\mathrm{Ca}$ and $\mathrm{Mg}$ behave in similar ways. This assumption holds only when the exchangeable $\mathrm{Mg}$ content is small as compared to the exchangeable $\mathrm{Ca}$ content. A high percentage of exchangeable $\mathrm{Mg}$ in the exchange complex may have deletcrious effects on soil-water relations (RowELL \& SHAINBERG, 1979 ; ALPEROVITCH et al., 1981).

A comparative kinetics study of $\mathrm{Ca}^{2+}, \mathrm{Na}^{+}$and $\mathrm{Mg}^{2+}$ exchange in two soils - Netanya and Bet Dagan - was carried out using the Eilat effluent. Figure 1 presents the cxchange occurring in soil columns during leaching with ten pore volumes of Eilat effluent and of a model solution. In both soils there is an accumulation of $\mathrm{Mg}$ during leaching with this effluent. The concentrations of the three cations in the leachate as a function of the leachate volume (fig. 1a-f) show that during leaching, $\mathrm{Na}^{+}$and $\mathrm{Mg}^{2+}$ replace $\mathrm{Ca}^{2+}$ in the soil. This is in agreement with the observed increase in the ESP after effluent irrigation.

\section{B. Colloidal plugging}

The decrease in soil $K_{\text {sat }}$ due to plugging by suspended solids was determined by leaching the soil columns with unfiltered Eilat effluent and with that effluent after different degrees of filtration (fig. 2). Some properties of the cffluents after filtration and the relative decrease in soil $\mathrm{K}_{\text {sat }}$ as a function of effluent quality are presented in table 3 . It is clear that the suspended solids have a major effect on the $\mathrm{K}_{\text {sat }}$ as the decrease in $\mathrm{K}_{\text {sat }}$ is correlated strongly with the amount of suspended solids in the effluent. The binding of bivalent cations has only a small effect on soil $\mathrm{K}_{\text {sat }}$ (notmore than a $10 \%$ decrease). Filtering the effluent through Whatman 91 filter paper excludes the coarse suspended solids but not the finer colloidal fraction. Passing through the soil column ten pore volumes of the effluent filtered through Whatman 91 filter paper led to a $20 \%$ decrease in the $\mathrm{K}_{\text {sat }}$ of the investigated soils as compared to more than $50 \%$ decrease when unfiltered effluent was applied to the soils.

The rate of decrease of the $K_{\text {sat }}$ of the Netanya and Bet Dagan soils when leached with the Eilat effluent after various filtrations is shown in figure 2 . The effect of the model solution is also presented. When the unfiltered effluent is applied to the soil, the rate of decrease is high.

TABLE 5

The effect of irrigation with effluents on the ESP of 2 soils and a standard clay.

Effet de l'irrigation avec des effluents sur le pourcentage de sodium échangeable de 2 sols et d'une argile standard.

\begin{tabular}{|c|c|c|c|}
\hline Solid medium & Source of the effluent & ESP & Method \\
\hline Bentonite & $\begin{array}{l}\text { Ramat Hasharon } \\
\text { Oxidation Pond } \\
\text { Model Solution }\left(\mathrm{SAR}_{\mathrm{T}}\right)\end{array}$ & $\begin{array}{l}12.9 \\
10.4\end{array}$ & $\begin{array}{l}\text { Batch runs repeated until } \\
\text { steady state was achieved }\end{array}$ \\
\hline Bet Dagan soil & $\begin{array}{l}\text { Eilat } \\
\text { Model solution }\left(\mathrm{SAR}_{\mathrm{T}}\right)\end{array}$ & $\begin{array}{l}10.7 \\
11.9\end{array}$ & Columns at steady state \\
\hline Netanya soil & $\begin{array}{l}\text { Gan Raveh } \\
\text { Model solution }\left(\mathrm{SAR}_{\mathrm{T}}\right) \\
\text { Model solution }\left(\mathrm{SAR}_{\mathrm{E}}\right)\end{array}$ & $\begin{array}{r}7.0 \\
6.0 \\
8.5 \\
14.5 \\
16.1 \\
18.0\end{array}$ & Columns at steady state \\
\hline
\end{tabular}



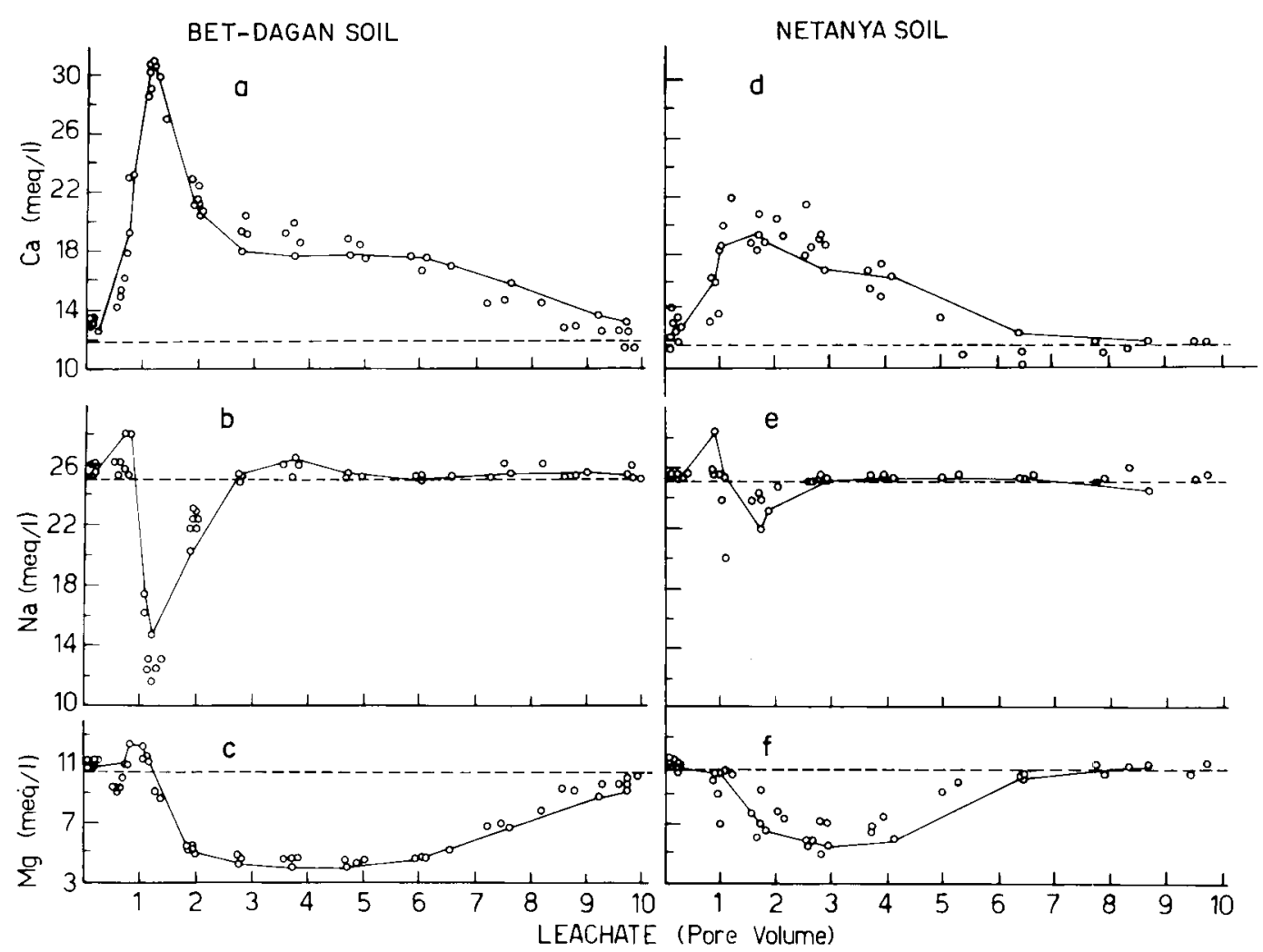

Figure 1

Changes in the concentrations of $\mathrm{Ca}^{2+}, \mathrm{Mg}^{2+}$ and $\mathrm{Na}^{+}$in the leachate during the leaching of 2 soils with Eilat effluents : $a, b, c$ Bet Dagan soil ; $d, e, f$ Netanya soil.

The full curves correspond to leaching with a model solution having the same cation concentrations as the effluent; horizontal lines represent the concentrations in the incoming effluents.
Evolution des concentrations en $\mathrm{Ca}^{2+}, \mathrm{Mg}^{2+}$ et $\mathrm{Na}^{+}$dans le lessivat durant le lessivage de 2 sols avec les effluents d'Eilat: $a, b, c$ sol de Bet Dagan; $d$, e, $f$ sol de Netanya.

Les courbes continues correspondent au lessivage avec une solution modèle ayant les mêmes concentrations en cations que l'effluent; les lignes horizontales représentent les concentrations dans les effluents avant leur pénétration dans le sol.

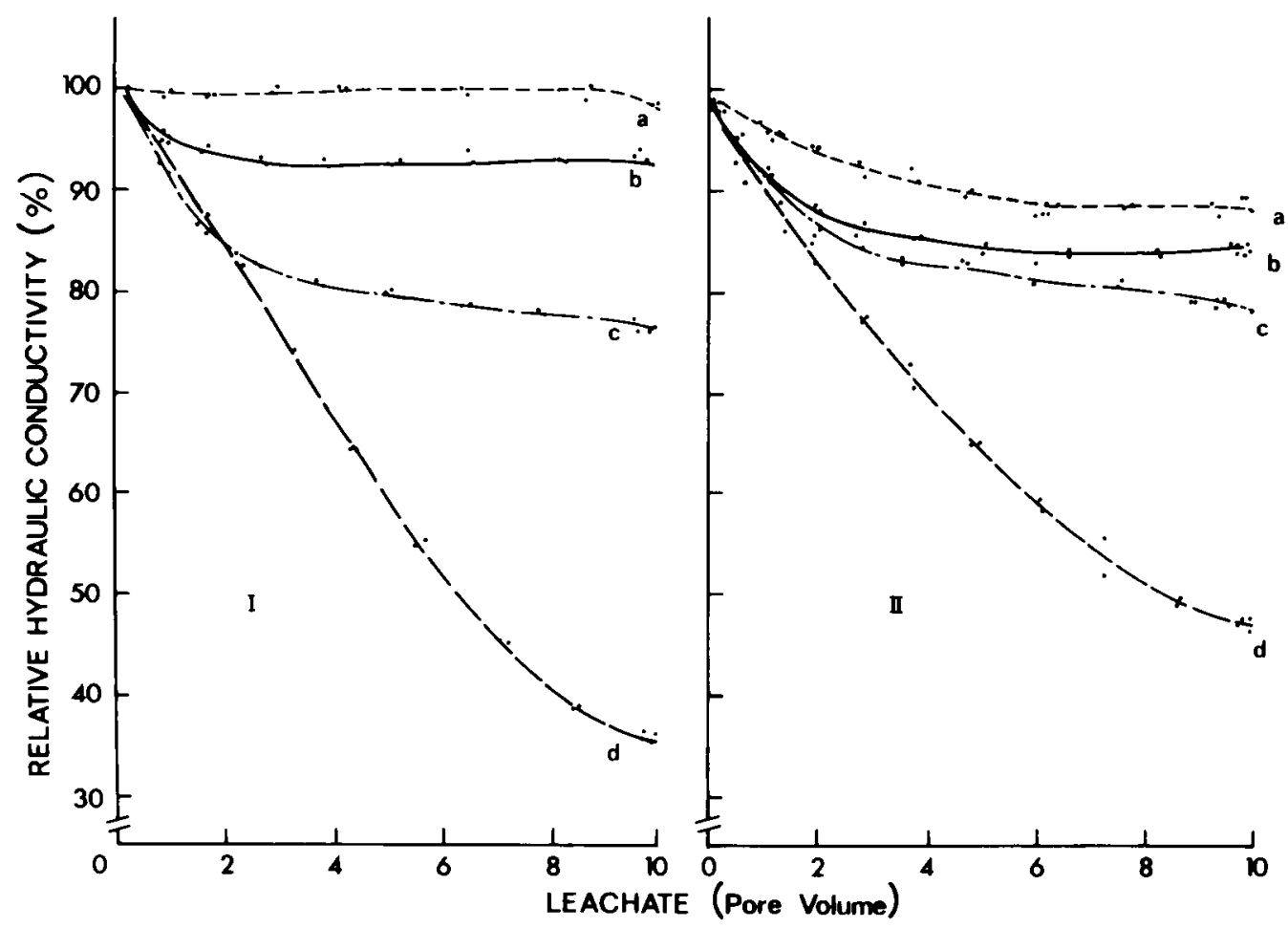

Figure 2

The effect of leaching with Eilat effluent after different degrees of filtration on the hydraulic conductivity of 2 soils : I, Netanya soil ; II, Bet Dagan soil.

$a$. Model solution; $b$. Effluent filtered through $0.45 \mu$ millipore filter; c. Effluent filtered through Whatman 91 filter paper; d. Unfiltered effluent.
Effet du lessivage avec des effluents d' Eilat soumis à différents degrés de filtration, sur la conductivité hydraulique de 2 sols: $I$, sol de Netanya; II, sol de Bet Dagan.

$a$. Solution modèle, $b$. Effluent filtré à travers un filtre millipore de $0,45 \mu$, c. Effluent filtré à travers du papier filtre Whatman 91, d. Effluent non filtré. 


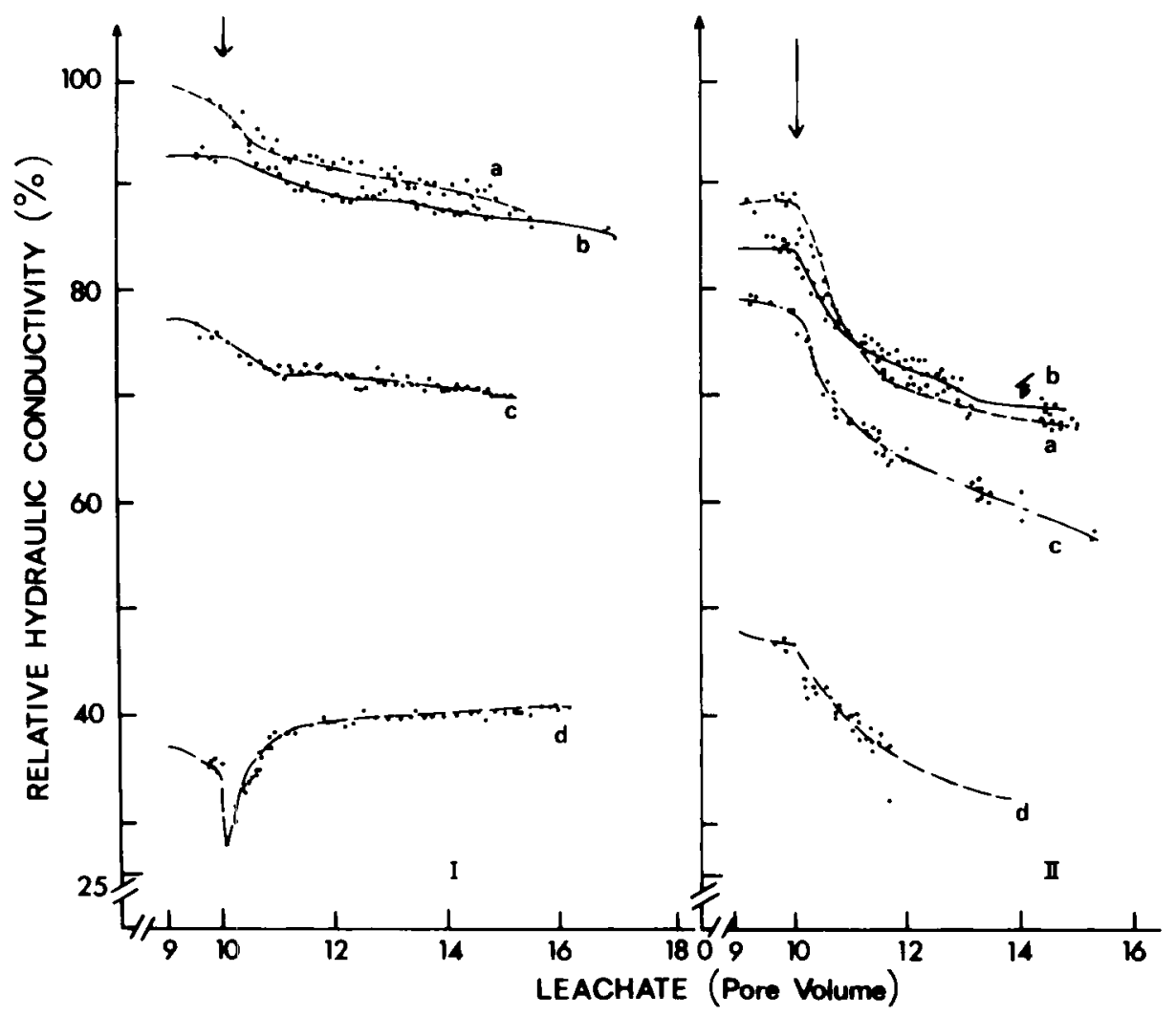

Figure 3

The effect of leaching with distilled water on the $K_{\text {sat }}$ of soils previously leached with Eilat effluents (see fig. 2 legend; the arrow indicates the beginning of the application of distilled water).

When the coarse suspended solids were removed by filtration with Whatman 91 filter paper, the rate of decrease was similar to that caused by the unfiltered effluent, until approximately two pore volumes of effluent passed through the column. The rate of plugging diminished greatly afterwards. The rate of reduction of the $\mathrm{K}_{\text {sat }}$ by the effluent filtered through millipore paper was yet slower and more similar to the rate observed for the model solution.

After the soil columns were leached with effluent or with model solution, they were eluted with distilled water (mimicking rain). As a result, the $\mathrm{K}_{\text {sat }}$ of the finer textured Bet Dagan soil decreased appreciably for the model solution and the effluents regardless of the extent of filtration (fig. 3II). When soil is percolated with water of low electrical conductivity (such as rain), clay swelling and dispersion are strong above a given ESP. Thus, while suspended solids affect the immediate $K_{\text {sat }}$, the effective SAR (namely the binding of polyvalent cations) may affect the $\mathrm{K}_{\text {sat }}$ during subsequent rain or irrigation with high quality water. Another difference between the long-term effects on $\mathrm{K}_{\text {sat }}$ of the cationic composition and of the suspended solids is that the first will cause a new equilibrium ESP in the soil, which will not change further upon addition of effluent of similar quality, while the latter causes a gradual plugging, which may increase for a long time as long as elution with the effluent continues (fig. 2).

In the Netanya soil, which has a coarser texture than Bet Dagan soil (see table 1), eluting with distilled water follo-
Effet du lessivage avec de l'eau distillée sur la conductivité hydraulique des sols lessivés préalablement avec les effluents d'Eilat (cf. légende fig. 2 ; la flèche indique le début de l'application d'eau distillée).

wing effluent irrigation reduced the $\mathrm{K}_{\mathrm{sat}}$ to a small extent (fig. 3-I). When elution with distilled water followed the unfiltered effluent, an interesting change of the $\mathrm{K}_{\mathrm{sat}}$ with time was observed. Adding water of low electrical conductivity to this sandy soil apparently causes dispersion and downward movement of the colloids. This phenomenon was observed in the Netanya soil for the native colloids (PUPISKY \& SHAINBERG, 1979). This will reduce the $\mathrm{K}_{\mathrm{sat}}$ during the dispersion stage, followed by an increase in the $\mathrm{K}_{\mathrm{sat}}$ as part of the plug is descending with the effluent. At the point where the moving colloids were flushed out (which should have occurred after more than one pore volume of distilled water passed - fig. 3-I), the $\mathrm{K}_{\text {sat }}$ stabilizes again.

Among the properties of sewage effluents applied to soils, which affect the $\mathrm{K}_{\mathrm{sat}}$, two might have not received their due consideration. The distribution in soil of the incoming suspended solids may reduce the $\mathrm{K}_{\text {sat }}$ significantly. The binding of polyvalent cations by polyelectrolytes or by ligands in the effluent is another factor which may affect the $\mathrm{K}_{\text {sat }}$, but its immediate effect is usually less pronounced. During subsequent rain, or irrigation with high quality water, the effect of this binding on the $K_{\text {sat }}$ through its influence on the ESP of the soil may in some cases be of some importance.

Reçu le 22 novembre 1982. Accepté le 13 avril 1983. 


\section{REFERENCES}

Acher A., Pistol Y., Yaron B., 1981. The use of gel chromatography for determination of bound $\mathrm{Ca}$ and $\mathrm{Mg}$ in sewage effluent - soil systems, pp. 211-220. In Shuval, H. (Editor). Developments in arid zone ecology and environmental quality. Balaban iss, Philadelphia. Alperovitch N., Shainberg I., Keren R., 1981. Specific effect of magnesium on the hydraulic conductivity of sodic soils. J. Soil Sci., 32 (4), 543-554.

Bower C. A., Ogata G., Zucker J. M., 1968. Sodium hazard of irrigation water as influenced by leaching fraction and by precipitation of solution of calcium carbonate. Soil Sci., 106 (1), 29-34.

Burns S., Rawitz E., 1981. The effect of sodium and organic matter in sewage effluent on water retention properties of soils. Soil Sci. Soc. am. J., 45 (3), 487-493.

Daniel T. C., Bouma J., 1974. Column studies of soil clogging in a slowly permeable soil as a function of effluent quality. $J$. environ. Qual., 3 (4), 321-326.

Frenkel H., Goertzen J. O., Rhoades J. D., 1978. Effects of clay type and content, ESP, and electrolyte concentration on clay dispersion and soil hydraulic conductivity. Soil Sci. Soc. am. J., 42 (1), 32-39.

Kristiansen R., 1981. Sand filter trenches for purification of septic tank effluent : I. The clogging mechanism and soil physical environment. J. environ. Qual., 10 (3), 353-357.

Pistol Y., 1981. Determination of the presence of organic complexes in sewage water and their influence on soil hydraulic conductivity. M. Sc. Thesis, Fac. of Agriculture, Hebrew University of Jerusalem, Rehovot, 56 p. (in Hebrew, English summary).
Pupisky H., Shainberg I., 1979. Salt effects on the hydraulic conductivity of a sandy soil. Soil Sci. Soc. am. J., 43 (3), 429-433. Quirk J. P., Schofield R. K., 1955. The effect of electrolyte composition on soil permeability. J. Soil Sci., 6 (2), 163-177.

Rowell D. L., Shainberg I., 1979. The influence of magnesium and of easily weathered minerals on hydraulic conductivity change in a sodic soil. J. Soil Sci:, 30 (4), 719-726.

Sposito G., Hotzclaw K. M., Levesque Madore C. S., 1978. Calcium ion complexation by fulvic acid extracted from sewage-sludge-soil mixtures. Soil Sci. Soc. am. J., 42 (4), 600-606.

Thomas R. E., Law J. P., 1968. Soil response to sewage effluent irrigation, pp. 5-19. In Wilson C. W. et al. (editors) Municipal sewage effluent for irrigation, Louisiana Polytechnic Institute, Louisiana.

Thomas R. E., Schwartz W. A., Bendixen T. W., 1966. Soil chemical changes and infiltration rate reduction under sewage spreading. Soil Sci. Soc. am. Proc,, 30 (5), 641-646.

Vinten A. J. A., Mingelgrin U., Yaron B., 1983. The effect of suspended solids in waste water on soil hydraulic conductivity. II Vertical distribution of suspended solids. Soil Sci. Soc. am. J., 47 (3), 408-412.

de Vries J., 1972. Soil filtration of waste water effluent and the mechanism of soil clogging. J. Water Pollut. Control. Fed., 44 (4), 565-573.

Yaron B., Bresler E., Shalhevet J., 1965. A method for uniform packing of soil columns. Soil Sci., 101 (3), 205-209. 